\title{
Structural and Characteristics of Manganese Doped Zinc Sulfide Nanoparticles and Its Antibacterial Effect against Gram-Positive and Gram-Negative Bacteria
}

\author{
Iftikhar M. Ali1 , Isam M. Ibrahim1', Entissar F. Ahmed², Qayes A. Abbas³ \\ ${ }^{1}$ Department of Physics, College of Science, University of Baghdad, Baghdad, Iraq \\ ${ }^{2}$ Department of Biology, College of Science, University of Baghdad, Baghdad, Iraq \\ ${ }^{3}$ Department of Physics, College of Education for Pure Science, University of Anbar, Ramadi, Iraq \\ Email: qaaal-dulaim1@sheffield.ac.uk
}

Received 9 October 2015; accepted 15 January 2016; published 18 January 2016

Copyright (C) 2016 by authors and Scientific Research Publishing Inc.

This work is licensed under the Creative Commons Attribution International License (CC BY).

http://creativecommons.org/licenses/by/4.0/

(c) (i) Open Access

\begin{abstract}
The Manganese doped zinc sulfide nanoparticles of the cubic zinc blende structure with the average crystallite size of about $3.56 \mathrm{~nm}$ were synthesized using a coprecipitation method using Thioglycolic Acid as an external capping agent for surface modification. The $\mathrm{ZnS}: \mathrm{Mn}^{2+}$ nanoparticles of diameter $3.56 \mathrm{~nm}$ were manufactured through using inexpensive precursors in an efficient and eco-friendly way. X-Ray Diffraction (XRD), Scanning Electron Microscopy (SEM) and Fourier Transform Infrared (FTIR) spectroscopy are used to examine the structure, morphology and chemical composition of the nanoparticles. The antimicrobial activity of $\left(\mathrm{ZnS}: \mathrm{Mn}^{2+}\right)$ nanocrystals was investigated by measuring the diameter of inhibition zone using well diffusion mechanism versus two various bacterial strains. The technique of microorganism inactivation was considered as sortsdependent. Bacillus subtilis showed the largest antibacterial sensitivity $(35 \mathrm{~mm})$ to $\mathrm{ZnS}: \mathrm{Mn}^{2+}$ nanoparticles at a concentration (50 mM) whereas Escherichia coli offered maximum zone of inhibition $(20 \mathrm{~mm})$ at the same concentration. In this study, the results indicated that $\mathrm{ZnS}: \mathrm{Mn}^{2+}$ nanoparticles were found to have significant antibacterial activity against Gram-negative $(E$. coli) and Gram-positive (Bacillus subtilis) bacteria.
\end{abstract}

\section{Keywords}

Zinc Sulfide, Nanoparticles, Co-Precipitation Method, Antibacterial Activity

How to cite this paper: Ali, I.M., Ibrahim, I.M., Ahmed, E.F. and Abbas, Q.A. (2016) Structural and Characteristics of Manganese Doped Zinc Sulfide Nanoparticles and Its Antibacterial Effect against Gram-Positive and Gram-Negative Bacteria. Open Journal of Biophysics, 6, 1-9. http://dx.doi.org/10.4236/ojbiphy.2016.61001 


\section{Introduction}

Recently, nanometer sized materials with their unique as well as interesting biophysical and biochemical properties have enticed a major transact of benefit in the scientific society. A reduction in the dimensions of material in the nanoscale range considerably changed the properties of materials. Scientists have expended a lot of research effort in characterizing and describing both the physical behaviour and chemical effect of semiconductor nanomaterial due to the exceptional promise in a wide range of technological applications [1]-[4] (Ueda et al. 2004). After discovering the Zinc sulfide (ZnS) as one of the initial semiconductors, shows marked substantial properties, versatility and is highly promising for novel different applications due to the existence of a large number of surface atoms and the three dimensional confinement of electrons [5]. Their outstanding potential applications derived from their properties like nonlinear optical with a luminescence that are controlled by quantum size influence as well as other significant physical and chemical properties [6]. Potential applications include lightemitting diodes, solar cells, optoelectronic devices, photocatalysis, luminescent nanocomposites, environmental and biological sensors [7]-[10]. It has been previously established that the direct bandgap II-VI semiconductor like ZnS as well as Zinc blende and Wurtzite crystal structure, which their band gap energies at room temperature equal to 3.68 and $3.80 \mathrm{eV}$ respectively [11].

In such work, it has reported that a novel one-step solid state reaction process which controls the volume of the structured nanoparticles and its influence on antimicrobial properties. The concentration of nanoparticles added to the growth medium directly affects its bactericidal property due to the maximal retention time which was provided the bacterium nanoparticles interaction. Bacterial cells are generally in the micron-size scope with extreme of them possessing cellular membranes that include pores in the nanoscale scope. Synthesizing nanoparticles through such bacterial pores results in the singular feature of passing the cell membrane. In order to achieve this, however, it is imperative to come up with revolutionary ways of preparing and designing nanoparticles enabling them to be stabilized sufficiently to significantly limit bacterial growth while passing the cell membrane.

\section{Experimental Part}

\subsection{Materials and Methods}

It has been prepared nanoparticles of the $\mathrm{ZnS}: \mathrm{Mn}^{2+}$ by the chemical co-precipitation process, as shown. Firstly, $50 \mathrm{ml}$ deionized water used to dissolve $\mathrm{Zn}(\mathrm{Ac})_{2}$ with $5 \mathrm{mM}$ concentrations and to obtain complete dissolution, the obtained molar solution was stirred for 20 minutes at $100^{\circ} \mathrm{C}$. Afterwards, $0.5 \mathrm{mM}$ from $\mathrm{MnCl}_{2}$ has been added to the mentioned solution. The addition of $6 \mathrm{mM}$ from thioacetamide (TAA) to the solution was drop by drop to be the sulfur source. After that, $5 \mathrm{ml}$ quantity of Thioglycolic Acid (TGA) (0.2 M) has been added during the reaction for the purpose of controlling the particle size of $\mathrm{ZnS}: \mathrm{Mn}^{2+}$. The product solution was stirred incessantly for 2 hours. In the last stage, filtering and washing many times by distilled water and ethanol have been done to the white acquired precipitate to eject organic capping and different byproducts created during the reaction process. Finally, an oven at $60^{\circ} \mathrm{C}$ used to dry the product for 5 hours. After adequate drying, a mortar and pestle were used to crush the precipitate to a fine powder.

\subsection{Characterization of $\mathrm{ZnS}: \mathrm{Mn}^{2+}$ Nanoparticles}

$\mathrm{X}$-ray diffraction has used to characterization the Synthesized $\mathrm{ZnS}: \mathrm{Mn}^{2+}$ nanoparticles and to determine the crystallinity, structure, and crystallite size. This has been done by a Shimadzu X-ray diffractometer with Cu-Ka radiations $(\lambda=0.15406 \mathrm{~nm})$ in the $2 \theta$ range from $20^{\circ}$ to $60^{\circ}$, Fourier-transform infrared spectroscopy (FTIR) spectra recorded in the solid case using the $\mathrm{KBr}$ pellets mechanism in the extent of $4000-400 \mathrm{~cm}^{-1}$. The size of the nanoparticles was exhibited by Scanning electron microscopy (SEM).

\subsection{The Well-Diffusion Process to Determine the Activity of Antimicrobial}

Different concentrations of the $\mathrm{ZnS}: \mathrm{Mn}^{2+}$ nanoparticles were used to determine the antimicrobial activities by using Gram-negative bacteria (E. coli) as well as Gram-positive bacteria (B. subtillis) following a well diffusion process adjustment of the disc diffusion process. Briefly, the bacteria were cultured in Müller-Hinton broth at the $37^{\circ} \mathrm{C}$ incubator [12]. Bacterial culture was prepared by spreading $100 \mu \mathrm{L}$ culture broth, possessing $10^{6}$ 
CFU/mL compared with every test organism on solid nutrient agar plates in McFarland tube. Allowing for culture absorption has done by allowing the plates to stand for 10 minutes to quarter an hour. The $8 \mathrm{~mm}$ volume wells were punched inside the agar with the head of sterilized micropipette tipsor cork borer. To prevent leakage from the bottom of the plate, Wells were sealed through a singular drop of molten agar ( $0.8 \%$ nutrient agar). Decant of $100 \mu \mathrm{L}$ of the nanoparticles solution sample into four wells on all plates by use a micropipette. The diameter of inhibition regions was measured, after nursery at $37^{\circ} \mathrm{C}$ for one day, a blank (solvent without $\mathrm{ZnS}: \mathrm{Mn}^{2+}$ nanoparticles) which run as a passive control.

\section{Results}

\subsection{Structural Analysis}

\subsubsection{XRD for ZnS: $\mathrm{Mn}^{2+} \mathrm{NPS}$}

Figure 1 shows the XRD pattern of the synthesized $\mathrm{ZnS}: \mathrm{Mn}^{2+}$ shows that there are no additional peaks of impurity could be discovered where three broad peaks are observed in the diffractrogram at around $28.84^{\circ}, 48.04^{\circ}$, $56.86^{\circ}$ corresponding to (111), (220) and (311) planes of cubic ZnS respectively. These broad peaks in the XRD confirm the presence of nanosized particles. No peaks of impurity phases were detected.

The average crystallite size was calculated using the Debye-Scherrer formula $D=K \lambda / \beta \cos \theta$, where $D$ is the crystallite size, $K$ is the geometric factor (0.9), $\lambda$ is the X-ray wave length (1.54 $\AA$ ), $\beta$ is the full width at half maxima (FWHM) of the diffraction peak (in radian) and $\theta$ is the diffraction angle. The calculated crystallite sizeof the prominent (111) plane is found to be $4.49 \mathrm{~nm}$. The FWHM of the XRD peaks may also contain contributions from the lattice strain [13]. Thus, the average strain of the ZnS nanoparticles was determined using Stokes-Wilson equation [14] ( $\left.\varepsilon_{\mathrm{str}}=\beta \cot \theta / 4\right)$ where $\beta$ and $\theta$ are the FWHM and the diffraction angle respectively. The rate of defects in the sample which denoted to the dislocation density $(\delta)$ can be calculated using the formula $\left(\delta=1 / D^{2}\right)$ where $D$ is dented to the average crystalline size [15]. The d-spacing is calculated using the relation $\left(d_{\mathrm{hkl}}=n \lambda / 2 \sin \theta\right)[16]$. From the Nelson-Riley plot which is represented the graph of the measured values of the lattice parameter for various planes against the error function can estimate the lattice constant as shown by [17]:

$$
f(\theta)=\frac{1}{2}\left(\frac{\cos ^{2} \theta}{\sin \theta}+\frac{\cos ^{2} \theta}{\theta}\right)
$$

From Figure 2 the lattice parameter of $\mathrm{ZnS}: \mathrm{Mn}^{2+}$ nanoparticles is $a=5.3635 \AA$ with unit cell volume 154.2839^3. Table 1 shows the structural parameters.

\subsubsection{SEM Analysis}

Figure 3 illustrates the SEM image of the $\mathrm{ZnS}: \mathrm{Mn}^{2+}$ NPs powder which clearly shows the size of particles to be less than $100 \mathrm{~nm}$. As expected, the prepared nanoparticles were found to be in cluster form. The surface morphology of the $\mathrm{ZnS}: \mathrm{Mn}^{2+} \mathrm{NPs}$ is spherical in shape. In some places, various sizes of the particles are observed, meaning that the nano-sized particles are randomly distributed.

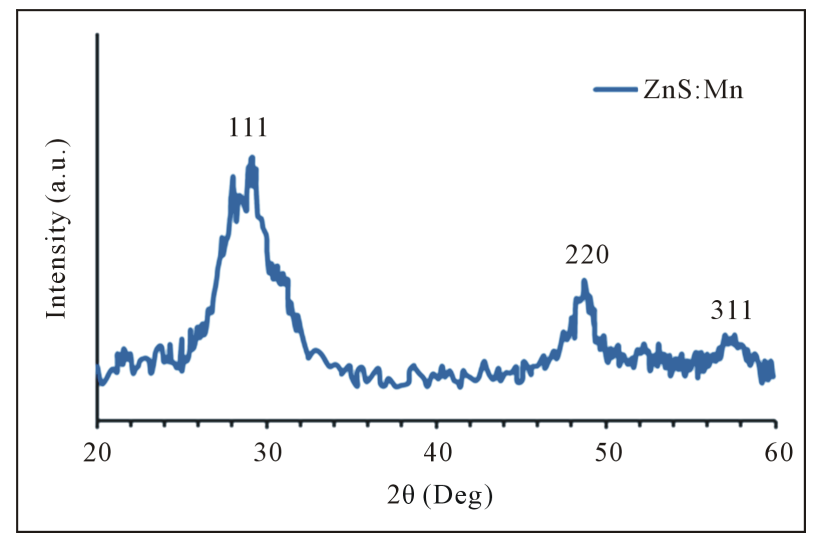

Figure 1. XRD pattern of $\mathrm{ZnS}: \mathrm{Mn}^{2+} \mathrm{NPs}$. The indices give against the corresponding planes. 


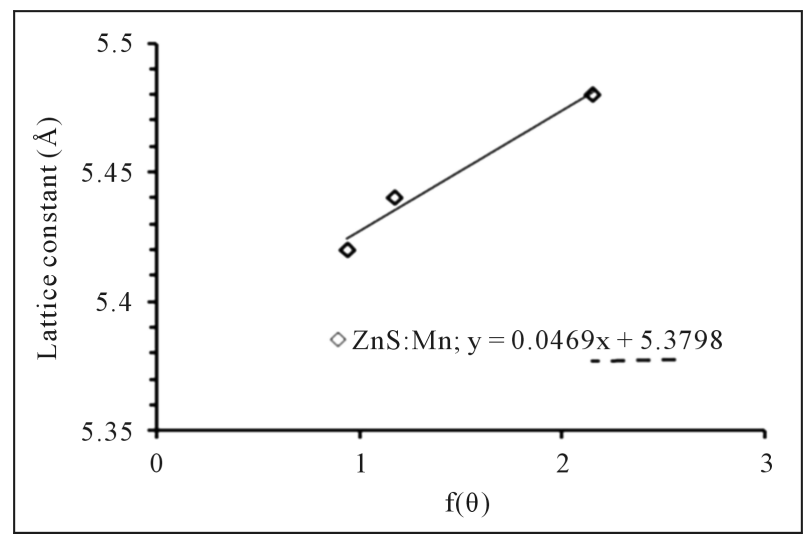

Figure 2. Nelson-riley plot of $\mathrm{ZnS}: \mathrm{Mn}^{2+} \mathrm{NPs}$.

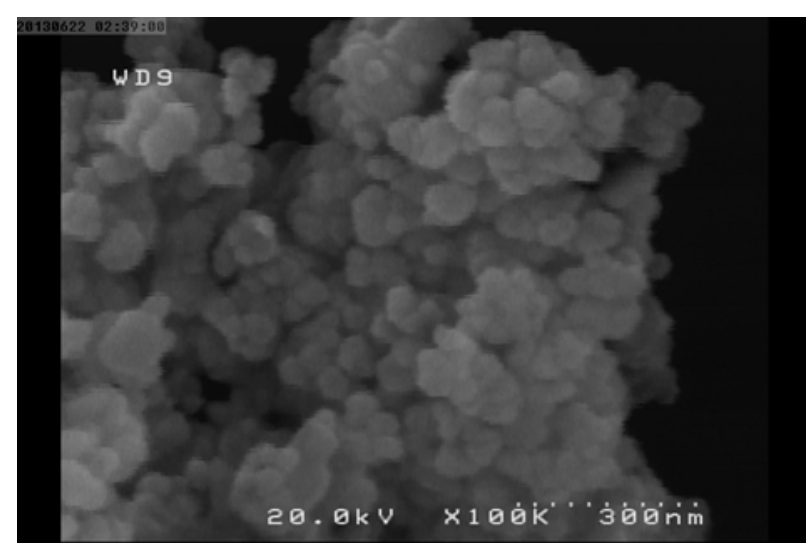

Figure 3. SEM image of $\mathrm{ZnS}: \mathrm{Mn}^{2+}$ nanoparticles.

Table 1. Structural properties of $\mathrm{ZnS}: \mathrm{Mn}^{2+} \mathrm{NPs}$.

\begin{tabular}{cccccccc}
\hline $2 \theta$ (degree) & Plane (hkl) & $\begin{array}{c}\text { Interplaner } \\
\text { Spacing } \\
d(\AA)\end{array}$ & $\begin{array}{c}\text { Lattice } \\
\text { Constant } \\
a(\AA)\end{array}$ & FWHM (deg) & $\begin{array}{c}\text { Average } \\
\text { Crystallite } \\
\text { Size } D(\mathrm{~nm})\end{array}$ & $\begin{array}{c}\text { Dislocation } \\
\text { Density } \\
\Delta\left(\text { lines } / \mathrm{m}^{2}\right)\end{array}$ & $\begin{array}{c}\text { Average } \\
\text { Strain }\left(\varepsilon_{\text {str }}\right)\end{array}$ \\
\hline 28.8440 & $(111)$ & 3.09281 & & 1.7768 & & & \\
48.0492 & $(220)$ & 1.89203 & 5.3635 & 1.6474 & 3.56 & $7.87 \times 10^{16}$ & $15.7 \times 10^{-3}$ \\
56.8629 & $(311)$ & 1.61791 & & 1.4750 & & \\
\hline
\end{tabular}

\subsubsection{FT-IR Analysis}

The FTIR spectra of ZnS: $\mathrm{Mn}^{2+}$ nanoparticles stabilized by TGA is shown in Figure 4. The purpose of the FTIR study is to identify the capping of the particles by TGA. The IR spectrum showed that the stretching bending corresponding to C-O around $1350-1450 \mathrm{~cm}^{-1}$ and the C-C linkages around $1000-1200 \mathrm{~cm}^{-1}$ for the prepared sample. This pointed that the ZnS nanoparticles could be capped with the TGA molecules. A powerful absorption band at $1600 \mathrm{~cm}^{-1}$ is attributed to S-O bending vibrations and $3000-3500 \mathrm{~cm}^{-1}$ band corresponds to the $\mathrm{O}-\mathrm{H}$ stretching vibrations. Another peak is found at $450 \mathrm{~cm}^{-1}$ of the characteristic of Zn-S vibrations. We can therefore infer that $\mathrm{ZnS}: \mathrm{Mn}^{2+}$ nanoparticles are encapsulated by TGA. These assignments are in acceptance with the results obtainable in the literature [18].

\subsection{Antimicrobial Properties}

\subsubsection{Action of ZnS: $\mathrm{Mn}^{2+} \mathrm{NPs}$ Singly}

From Table 2, it can be seen that $\mathrm{ZnS}: \mathrm{Mn}^{2+}$ NPs showed remarkable antibacterial effective against together 
Gram-positive (B. subtilis) as well as Gram-negative (E. coli) bacteria. The range of restraint of bacterial growth noticed in this research was observed to be changeable. $\mathrm{ZnS}: \mathrm{Mn}^{2+}$ nanoparticles of particle size $3.56 \mathrm{~nm}$, showed a significant inhibitory effect against Gram positive more than that for Gram negative bacteria as shown in Figure 5. $\mathrm{ZnS}: \mathrm{Mn}^{2+}$ nanoparticles showed that the greatest zone of restraint in the status of $B$. subtilis, which was around $50 \%$ greater than the zone of inhibition found for E. coli. It was also observed that the zone of inhibition increases with $\mathrm{ZnS}: \mathrm{Mn}^{2+}$ concentration and this is an agreement with the result of Wang et al. [19], (see Table 2). Table 2, clearly shows that $\mathrm{ZnS}: \mathrm{Mn}^{2+}$ nanoparticles were more effective on $B$. subtilis than $E$. coli. Furthermore, the greater sensitivity of Gram positive organisms by $\mathrm{ZnS}: \mathrm{Mn}^{2+}$ was confirmed by this test. Clearly, from Table 2 that nanoparticles showed maximal antimicrobial activity against B. The alteration in the sensitivity or resistance to both Gram-positive as well as negative bacteria populations probably as a result of the variations in

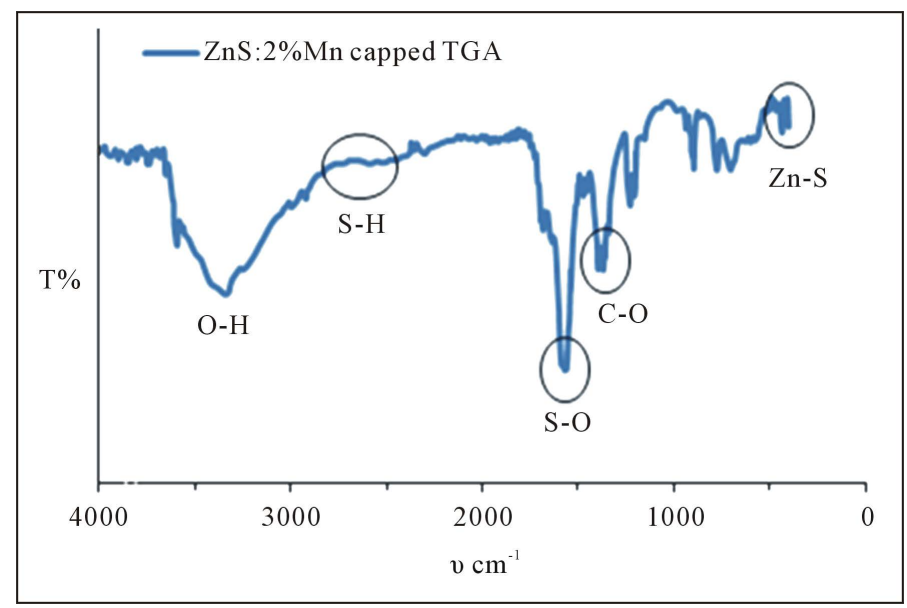

Figure 4. FTIR (Infrared) Spectra, nanoparticles of $\mathrm{ZnS}: \mathrm{Mn}^{2+} \mathrm{Nano}-$ particles capped with TGA. The inset is (TGA) the organic compound $\mathrm{HSCH}_{2} \mathrm{CO}_{2} \mathrm{H}$.

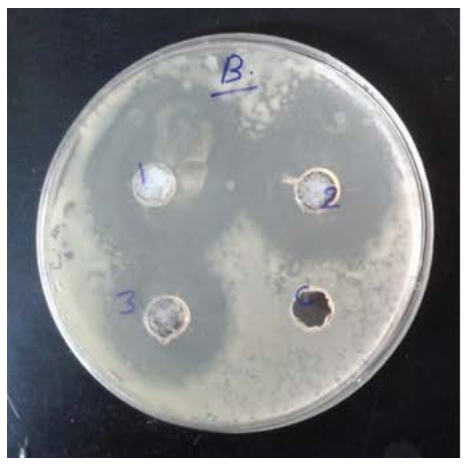

(a)

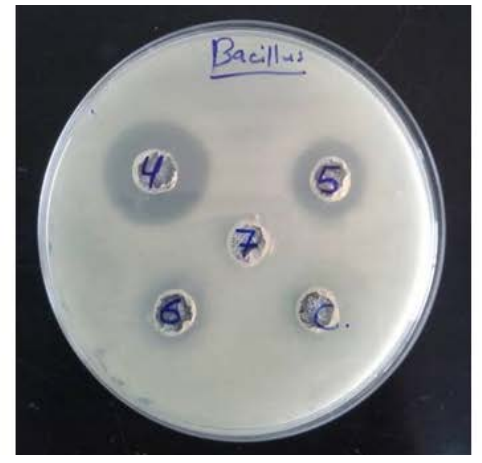

(b)

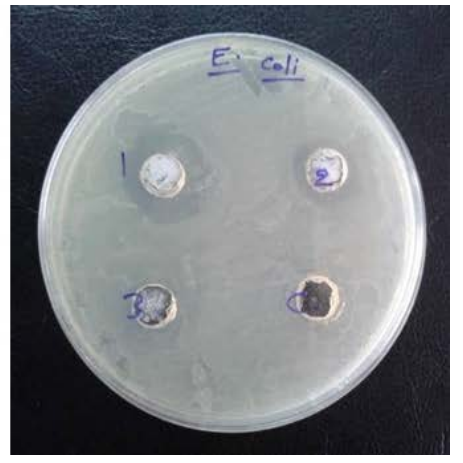

(c)

Figure 5. Zone of inhibition of ZnS: $\mathrm{Mn}^{2+}$ nanoparticles. Notes: Zone of inhibition of $\mathrm{ZnS}: \mathrm{Mn}^{2+} \mathrm{NPs}$ at different concentrations (1 - 7) indicate to concentrations (50, 20, 10, 5, 3.3, 2, 1) mM and positive control, a bacteria (c) Escherichia coli.

Table 2. Antimicrobial activity of $\mathrm{ZnS}: \mathrm{Mn}^{2+}$ nanoparticles against $E$. coli and B. subtillis determined by well diffusion technique.

\begin{tabular}{|c|c|c|c|c|c|c|c|c|}
\hline \multirow{2}{*}{ Bacteria } & \multicolumn{8}{|c|}{ Diameters of inhibition zones in mm according to the amount of $\mathrm{ZnS}$ applied in each well } \\
\hline & $\begin{array}{c}10 \mu \mathrm{g} \\
(1 \mathrm{mM})\end{array}$ & $\begin{array}{c}20 \mu \mathrm{g} \\
(2 \mathrm{mM})\end{array}$ & $\begin{array}{c}33 \mu \mathrm{g} \\
(3.3 \mathrm{mM})\end{array}$ & $\begin{array}{c}50 \mu \mathrm{g} \\
(5 \mathrm{mM})\end{array}$ & $\begin{array}{c}100 \mu \mathrm{g} \\
(10 \mathrm{mM})\end{array}$ & $\begin{array}{c}200 \mu \mathrm{g} \\
(20 \mathrm{mM})\end{array}$ & $\begin{array}{c}500 \mu \mathrm{g} \\
(50 \mathrm{mM})\end{array}$ & contro \\
\hline E. coli & ---- & ---- & --- & ---- & ---- & 15 & 20 & ---- \\
\hline B. subtillis & ---- & 12 & 16 & 24 & 27 & 32 & 35 & ---- \\
\hline
\end{tabular}


the cell structure, metabolism, physiology or degree of touching of organisms with nanoparticles. It has been previously established that greater sensitivity among Gram-positive bacteria like B. subtilis and nanoparticles have been referred to the maximal abundance of amines and carboxyl groups on their cell surface and greater cognation of $\mathrm{ZnS}: \mathrm{Mn}^{2+}$ to these groups [20]. Bacteria such as E. coli possesses a particular cell membrane synthesis, which have a significant ability to resist antimicrobial agents [21]. In addition, other parameters like nanoparticle diffusion rates probably, also influence bacterial strain variously.

\subsubsection{Action of ZnS: $\mathrm{Mn}^{2+}$ NPs Combined with Antibiotics by Well Diffusion}

The search for antimicrobials has now been expanded to a category of compounds familiar as "non-antibiotics" due to the issue of drug resistance among bacterial pathogens which are employed for the treatment of non-infectious pathology and which demonstrate significant antimicrobial activity against some of the most pathogenic infectious agents [22] [23]. Our present study indicates the potential of antibiotic (Cephlaxene) as a noteworthy antimicrobial agent since it has shown a significant inhibitory effect against pathogenic bacteria. Furthermore, the antimicrobial efficiency of antibiotics was enhanced when tested in combination with $\mathrm{ZnS}: \mathrm{Mn}^{2+}$ nanoparticles as revealed by the study of the determination of synergism.

Since these results reveal that the combination of $\mathrm{ZnS}: \mathrm{Mn}^{2+}$ nanoparticles and antibiotics possess potent antibacterial action, extra efforts are in progress to search the potential of their implementation in routine treatment against contagions of animals as shown in Figure 6.

Antibiotics being inhibitory for both Gram positive and negative bacteria were tested combinedly with $\mathrm{ZnS}: \mathrm{Mn}^{2+}$ nanoparticles by well diffusion assay in the same plate. Singly $730 \mu \mathrm{g}$ Cephlaxene produced $42 \mathrm{~mm}$ wide zone of inihibition against $B$. subtilis while the same against $E$. coli was $22 \mathrm{~mm}$ wide. In combination with $200 \mu \mathrm{g} \mathrm{ZnS}: \mathrm{Mn}^{2+}$ the diameter became $45 \mathrm{~mm}$ for B. subtilis and $27 \mathrm{~mm}$ for E. coli strains (Table 3).

\section{Discussion}

A few studies have been accomplished to explain the mechanism of bactericidal activity of nanoparticles. For example, Tsao et al. [24] investigated the exposure of Gram-positive bacteria to carboxy fullerene nanoparticles, which resulted in the puncturing of the bacteria resulting in a cell death. The alteration of membrane lipid components is another way in which the membrane can be compromised [25]. However, it is still deemed difficult to
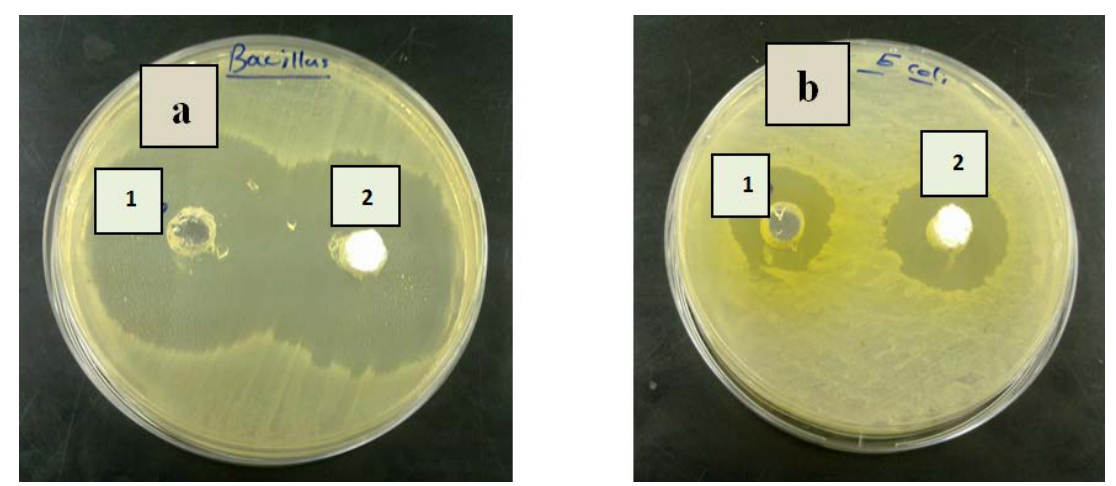

Figure 6. Zone of inhibition of (a) Gram-positive bacteria Bacillus subtilis (b) Gramnegative bacteria Escherichia coli. [Note: (1) antibiotic without $\mathrm{ZnS}: \mathrm{Mn}^{2+}$ nanoparticles (2) antibiotic with $\left.\mathrm{ZnS}: \mathrm{Mn}^{2+} \mathrm{NPs}\right]$.

Table 3. In vitro antibacterial activity of $\mathrm{ZnS}: \mathrm{Mn}^{2+}$ nanoparticles and imatinib alone and in combination with each other.

\begin{tabular}{c|cc}
\hline \multirow{2}{*}{ Bacteria } & \multicolumn{2}{|c}{ Diameters of inhibition zones in mm } \\
\cline { 2 - 3 } & Cephlaxene $(730 \mu \mathrm{g})$ & $\mathrm{ZnS}: \mathrm{Mn}^{2+}(200 \mu \mathrm{g})+$ Cephlaxene $(730 \mu \mathrm{g})$ \\
\hline E. coli & 22 & 27 \\
B. subtillis & 42 & 45 \\
\hline
\end{tabular}


distinguish between the bactericidal activity of nanoparticles from the ions released by the nanoparticles [26]. The continuous release of ions into the nutrient media is guaranteed by the presence of nanoparticles in suspension [27]. Previous studies have established a few mechanisms of nanoparticle toxicity such as the protein denaturation and cell death. This is caused by copper ions released by the nanoparticles attaching to the negatively charged bacterial cell wall and rupturing it. Cross-linking within and between the nucleic acid strands results in the disorganization of the helical structure when the copper ions in the bacterial cells bind to the deoxyribonucleic acid molecules. It has also been established that damage to important biochemical processes can be caused by copper ion uptake by the bacterial cells [28]. Stabilizers like surfactants (in this case, thioglycolic acid) was a critical function in stabilizing nanoparticles and discomfit agglomeration to control particlesize, protective agent as surfactant was added through the procedure of nanoparticles forming, the surfactant takes shape a layer of molecular membrane surround the nanoparticles that equips steric hindrance between nanoparticles. Surfactants play a pivotal role in attacking the charged macromolecules found in the cell wall of bacteria. For the control and prevention of bacterial infection, the cell wall of pathogenic bacteria is the main target because it is composed of surface proteins for adhesion and colonization. Also for components like polysaccharides, as well as teichoic acid, these macromolecules protect bacteria from host defense also environmental conditions. For example, the long chains polycations surfactant that coat the nanoparticles have ability to kill both gram positive and gram negative bacteria. Membrane disorganization which increases the membrane permeability results in the accumulation of nanoparticles in the bacterial membrane and cytoplasm regions of the cells that could explain the antibacterial activity [29]. When the particle size is small, the zone of inhibition is maximized. Consequently, these results pretend the excellent antimicrobial behaviour of nanoparticles. Hence, interactions between the negative charges of microorganisms and the positive charge of nanoparticles produce an electromagnetic attraction between the microbe and effective levels of active nanoparticles, this led to their death by oxidation of surface molecules of microbes. The exposure of Gram-positive bacteria to silver as well as copper nanoparticles led to the biodestructive effects like degradation of deoxyribonucleic acid as reported by other researchers [30], and is also accepted with current research findings.

\section{Conclusion}

According to the immediate progress of nanotechnology, different semiconductor nanoparticles have shown promise as powerful antimicrobial agents against microorganisms. In this current study, we present non toxic nanomaterials, which prepared by using a simple and effective method and showed considerable promise as antibacterial agents. Therefore, this present investigation is useful in respect of authenticating the nanoparticles to be a potential antibacterial agent. In addition that, this study is quite introductory, it supplies helpful insights to the evolution of novel antibacterial agents. Meanwhile, we are working on giving more detailed experimental evidences to explain the mechanism of antibacterial influence of $\mathrm{ZnS}: \mathrm{Mn}^{2+} \mathrm{NPs}$.

\section{Acknowledgements}

The authors appreciatively acknowledge the financial support of Baghdad University, College of Science, Biology department.

\section{References}

[1] Ueda, N., Maeda, H., Hosono, H. and Kawazoe, H. (1998) Band-Gap Widening of CdO Thin Films. Journal of Applied Physics, 84, 6174-6177. http://dx.doi.org/10.1063/1.368933

[2] Liu, H., Zhang, X. and Li, L. (2007) Role of Point Defects in Room-Temperature Ferromagnetism of Cr-Doped ZnO. Applied Physics Letters, 91, Article ID: 072511. http://dx.doi.org/10.1063/1.2772176

[3] Zhu, H., Zhao, F. and Pan, L. (2007) Structural and Magnetic Properties of Mn-Doped CuO Thin Films. Journal of Applied Physics, 101, Article ID: 09H111. http://dx.doi.org/10.1063/1.2711711

[4] Ferreira, F.F., Tabacniks, M.H., Fantinia, M.C.A., Fariab, I.C. and Gorensteinb, A. (1996) Electrochromic Nickel Oxide Thin Films Deposited under Different Sputtering Conditions. Solid State Ionics, 86-88, 971-976. http://dx.doi.org/10.1016/0167-2738(96)00236-6

[5] Li, X.Q., Xu, H.Z., Chen, Z.-S. and Chen, G.F. (2011) Biosynthesis of Nanoparticles by Microorganisms and Their Applications. Journal of Nanomaterials, 16, Article ID: 270974. http://dx.doi.org/10.1155/2011/270974

[6] Serrano, T., Cavazos, J., Peña, Y. and Gómez, I. (2014) Synthesis and Characterization of PbS/ZnS Core/Shell Nano- 
particles by Microwave Method. Chalcogenide Letters, 11, 21-28.

[7] Soltani, N., Saion, E. and Hussein, M.Z. (2012) Microwave Irradiation Effects on Hydrothermal and Polyol Synthesis of ZnS Nanoparticles. Chalcogenide Letters, 9, 265-274.

[8] Nezhad, A.M. and Dizaji, H.R. (2013) Synthesis and Characterization of CdS:Zn Nanoparticles by Microwave Irradiation Method. Journal of Applied Chemistry, 7, 25.

[9] Singh, K., Sharma, K., Kumer, M., Sundaram, S., Dutta, R. and Pandey, C. (2014) Red Luminescent ManganeseDoped Zinc Sulphide Nanocrystals and Antibacterial Study. Journal of Materials Chemistry B, 2, 522-528. http://dx.doi.org/10.1039/C3TB21363C

[10] Mathew, M., Mohan, J., Manzoor, K., Nair, S., Tamura, H. and Jayakumar, R. (2010) Folate Conjugated Carboxymethyl Chitosan-Manganese Doped Zinc Sulphide Nanoparticles for Targeted Drug Delivery and Imaging of Cancer Cell. Carbohydrate Polymers Elsevier Science, 80, 2442-2448.

[11] La Porta, F.A., Ferrer, M.M., de Santana Santana, Y.V.B., Raubach, C.W., Longo, V.M., et al. (2013) Synthesis of Wurtzite ZnS Nanoparticles Using the Microwave Assisted Solvothermal Method. Journal of Alloys and Compounds, 556, 153-159. http://dx.doi.org/10.1016/j.jallcom.2012.12.081

[12] Magaldin, S., Mata-Essayag, S., de Capriles, C.H., Colella, M.T., Olaizola, C. and Ontiverous, Y. (2004) Well Diffusion for Antifungal Susceptibility Testing. International Journal of Infectious Diseases, 8, 39-45. http://dx.doi.org/10.1016/j.ijid.2003.03.002

[13] Rita, J. and Sasi, F.S. (2009) Structural and Optical Properties of ZnS Nanoparticles Synthesized by Solid State Reaction Method. Chalcogenide Letters, 6, 535-539.

[14] Anayara, B., Amir, H. and Atowar, R. (2012) Effect of Deposition Temperature on the Structural and Optical Properties of Chemically Prepared Nanocrystalline Lead Selenide Thin Films. Beilstein Journal of Nanotechnology, 3, 438443. http://dx.doi.org/10.3762/bjnano.3.50

[15] Dhanam, M., Kavitha, B. and Velumani, S. (2010) An Investigation on Silar $\mathrm{Cu}\left(\mathrm{In}_{1-\mathrm{x}} \mathrm{Al}_{\mathrm{x}}\right) \mathrm{Se}_{2}$ Thin Films. Materials Science and Engineering: B, 174, 209-215. http://dx.doi.org/10.1016/j.mseb.2010.03.028

[16] Dhanam, M., Kavitha, B., Neetha, J. and Devasia Dheera, P. (2009) Analysis of ZnS Nanoparticles Prepared by Surfactant Micelle-Temperature Inducing Reaction. Chalcogenide Letters, 6, 713-722.

[17] Sarma, K., Sarma, R. and Das, H.L. (2008) Structural Characterization of Thermally Evaporated CdSe Thin Films. Chalcogenide Letters, 5, 153-163.

[18] Ummartyotin, S., Bunnak, N., Juntaro, J., Sain, M. and Manuspiya, H. (2012) Synthesis and Luminescence Properties of ZnS and Metal (Mn, Cu)-Doped-ZnS Ceramic Powder. Solid State Sciences, 14, 299-304. http://dx.doi.org/10.1016/j.solidstatesciences.2011.12.005

[19] Wang, C., Liu, L., Zhang, A., Xie, P., Lu, J. and Zou, X. (2012) Antibacterial Effects of Zinc Oxide Nanoparticles on Escherichia coli K88. African Journal of Biotechnology, 11, 10248-10254.

[20] Beveridge, T.J. and Murray, R.G. (1980) Sites of Metal Deposition in the Cell Wall of Bacillus subtilis. Journal of Bacteriology, 141, 876-887.

[21] Liang, X.X., Sun, M.X., Li, L.C., Qiao, R., Chen, K.Y., Xiao, Q.S. and Xu, F. (2012) Preparation and Antibacterial Activities of Polyaniline/ $\mathrm{Cu}_{0.05} \mathrm{Zn}_{0.95} \mathrm{O}$ Nanocomposites. Dalton Transactions, 41, 2804-2811. http://dx.doi.org/10.1039/c2dt11823h

[22] Dasgupta, A., Dastidar, S.G., Shiratki, Y. and Motohashi, N. (2008) Antibacterial Activity of Artificial Phenothiazines and Isoflavones from Plants. In: Motohashi, N., Ed., Bioactive Heterocycles VI, Topics in Heterocyclic Chemistry, Vol. 15, Springer, Berlin, 67-132. http://dx.doi.org/10.1007/7081_2007_108

[23] Jeyaseeli, L., Dasgupta, A., Dastidar, S.G., Molnar, J. and Amaral, L. (2012) Evidence of Significant Synergism between Antibiotics and the Antipsychotic, Antimicrobial Drug Flupenthixol. European Journal of Clinical Microbiology \& Infectious Diseases, 31, 1243-1250. http://dx.doi.org/10.1007/s10096-011-1435-3

[24] Tsao, N., Luh, T.Y., Chou, C.K., Chang, T.Y., Wu, J.J., Liu, C.C. and Lei, H.Y. (2002) In Vitro Action of Carboxyfullerene. Journal of Antimicrobial Chemotherapy, 49, 641-649. http://dx.doi.org/10.1093/jac/49.4.641

[25] Koch, M., Reynolds, F., Merkle, P., Weissleder, R. and Josephson, L. (2005) Transport of Surface-Modified Nanoparticles through Cell Monolayers. ChemBioChem, 6, 337-345. http://dx.doi.org/10.1002/cbic.200400174

[26] Yoon, K., Hoon Byeon, J., Park, J.H. and Hwang, J. (2007) Susceptibility Constants of Escherichia coli and Bacillus subtilis to Silver and Copper Nanoparticles. Science of the Total Environment, 373, 572-575. http://dx.doi.org/10.1016/j.scitotenv.2006.11.007

[27] Cioffi, N., Ditaranto, N., Torsi, L., Picca, R.A., Sabbatini, L., Valentini, A., Novello, L., Tantillo, G., Bleve-Zacheo, T. and Zambonin, P.G. (2005) Analytical Characterization of Bioactive Fluoropolymer Ultra-Thin Coatings Modified by Copper Nanoparticles. Analytical and Bioanalytical Chemistry, 381, 607-616. 
http://dx.doi.org/10.1007/s00216-004-2761-4

[28] Kim, J.H., Cho, H., Ryu, S.E. and Choi, M.U. (2000) Effects of Metal Ions on the Activity of Protein Tyrosine Phosphatase VHR: Highly Potent and Reversible Oxidative Inactivation by $\mathrm{Cu}^{2+}$ Ion. Archives of Biochemistry and Biophysics, 382, 72-80. http://dx.doi.org/10.1006/abbi.2000.1996

[29] Jones, N., Ray, B., Ranjit, K.T. and Manna, C. (2008) Antibacterial Activity of ZnO Nanoparticles Suspensions on a Broad Spectrum of Microorganisms. FEMS Microbiology Letters, 279, 71-76. http://dx.doi.org/10.1111/j.1574-6968.2007.01012.x

[30] Hosseinkhani, P., Zand, A.M., Imani, S., Rezayi, M. and Rezaei-Zarchi, S. (2010) Determining the Antibacterial Effect of $\mathrm{ZnO}$ Nanoparticle against the Pathogenic Bacterium Shigella dysenteriae (Type 1). International Journal of Nano Dimension, 1, 279-285. 